\title{
Motility and Energy Taxis of Salmonella spp.
}

\author{
Andreas E. Zautner \\ Universitätsmedizin Göttingen \\ Germany
}

\section{Introduction}

\subsection{Flagellar motility}

The essential morphological prerequisite for active bacterial motility is the flagellum. Besides that, only flotation with the help of self-produced gas vesicles in some cyanobacteria and gliding of filamentous rod-shaped bacteria are known mechanisms of flagella-independent active motion (Madigan \& Martinko, 2006). The flagellum is a taillike protrusion that can be found in many bacterial species. Besides its main function locomotion - it is also involved in passing the mucosa barrier (Erdem et al., 2007), regulation of auto-aggregation (Ulett et al., 2006), aggregation on solid surfaces, which precedes biofilm formation (O'Toole \& Kolter, 1998), and in the export of virulence factors and other proteins (Samudrala et al., 2009). Some bacteria own even more than one flagellum. According to number and arrangement of flagella, different schemes are distinguished (Hahne et al. 2004). Monotrichous bacteria, like Vibrio cholerae have only a single flagellum at one cell pole. The amphitrichous flagella arrangement scheme is characterized by single flagella on each of both cell poles, as observable for most Campylobacter spp. Lophotrichous flagellated bacteria, e.g. Pseudomonas aeruginosa, have multiple flagella on one cell pole and peritrichous bacteria, like Salmonella spp. have multiple flagella randomly distributed over the whole cellular surface.

The flagellum acts in principle like a marine screw propeller. Its rotational direction is by definition described by an external observer looking down the flagellar filament toward the bacterial cell (Adler, 1975). The flagellar mechanics is the only known real-rotating joint in the biological world. Its rotation frequency is around $100 \mathrm{~Hz}$ (Lauga et al., 2006). The direction of the flagellar motor and in consequence of the flagellar filament determines whether there is a thrust or drag impulse acting on the bacterium. The rotational direction can be reversed in a very short time, thus thrust and drag impulse momentum can switch suddenly. In general, the flagellum pushes the bacterium by providing a pressure gradient, which is relatively high near the filament and acts as a centrifugal force (Gebremichael et al., 2006). According to the physical law of the conservation of the angular momentum, the bacterial body rotates slowly in the counter direction at a rotation frequency of about $10 \mathrm{~Hz}$ (Lauga et al., 2006). A counter-clockwise rotation of the flagella causes a bacterial cell to move straight forwards, whereas a clockwise rotation causes the bacterium to tumble. The bacterial movement is controlled by conformational transitions in the flagellar filament between left- and right-handed supercoils (Kitao et al. 2006). These transitions are realized 
by a high flexible structure of the flagellar filament, due to "sliding"-interactions and "switch"-interactions", which stabilize inter- and intrasubunit interactions (Kitao et al. 2006). In case of a counter-clockwise flagellar rotation, several filaments of a left-handed helical structure form a bundle and act as propeller. If the flagellar motor rotates clockwise a transition into a right-handed helix of the filament structure is induced and the bundle is feazed (Larsen et al. 1974). The flagella of peritrichous bacteria are synchronized some way that they all rotate in the same orientation. They unite to form a rear-facing bundle that pushes the bacterium forward (Adler, 1975). In amphitrichous bacteria, the flagella of both poles rotate in opposite directions. Thus, the flagellum of the rear-end rotates comparable to monotrichous bacteria in order to provoke a thrust impulse, whereas the flagellum of the bow-end is bent backwards and turns around the front end of the bacterium. Thereby, the thrust impulse is increased. If the direction of the flagellar rotation is reversed, the filaments are fold over. The rear-end of the bacterium becomes the bow-end and the bow-end becomes the rear-end. In consequence, the bacterium swims in the opposite direction. In case of Gram-negative bacteria like Salmonella sp., the process of active bacterial movement is divided into continuously alternating phases of slow, non-directed movement called "tumbles" and phases of fast, straight-lined movement called "runs" (Adler, 1975). During a "tumble", the bacterium stops and turns in a more or less randomly chosen direction. It is a passive phase of re-orientation due to a rotational motion, where the non-spherical shape of the bacterial cell affects the way that it is rotated by the shear flow of the surrounding medium. Then the bacterium starts a fast, rectilinear "run", driven by the rotation of the flagella until it stops again and the next motion cycle begins. When the rotational direction of the flagella of peritrichous-flagellated bacteria is to be inverted, the individual flagellum is directed radially from the bacterial cell body in a way that it is sticking out. The dragging effects on the bacterial body outweigh each other to the mean positions in which the bacterium tumbles in a random motion in one place. The reversal of the flagellar rotation and the associated change in the direction of motion plays an important role in (chemo)tactic movements (Adler, 1975).

\subsection{Chemotaxis}

Chemotaxis is the process in which bacteria direct their locomotion dependent on the concentration of certain substances in their environment. Compounds affecting chemotaxis are called chemotaxins or chemoeffectors. Chemotaxis in the direction of a higher concentration of the chemoeffector is defined as positive and these kind of compounds are called chemoattractors. On the contrary, chemotaxis away from the higher concentration is defined as negative and these chemotaxins are called chemorepellents. Energy sources usually attract motile bacteria whereas bacteriotoxic agents act as repellents (Fig. 1). The finding, that bacteria move actively towards or away from certain substances, was already made at the end of the 19th century by Engelmann (Engelmann, 1881) and Pfeffer (Pfeffer, 1884 \& 1888). Thus, with the help of chemotaxis bacteria direct their movement to find favourable niches with high chemoattracor and low chemorepellent concentrations. This decision-making is based on temporal sensing. As indicated above the overall motion of a bacterium is composed of alternating phases of straight swimming and thumbling. In the presence of a chemical gradient the straight swimming phases last longer, and if the bacterium is moving nat along this gradient, it starts sooner to tumble and tries to reorientate depending on the chemotaxins 
concentration (Adler, 1975). The essential prerequisites for chemotaxis are, as already mentioned, a flagella mediated motility, a variety of individual chemoreceptors and a highly conserved chemosensory signal-transduction system.

\section{Flagellar motility and chemotaxis}

\subsection{Experimental approaches}

Before the mechanisms of flagellar motility and chemotaxis will be discussed, the most common tools or experimental approaches to study and record bacterial motility and taxis will be presented: microscopy and chemotaxis assay.

\subsubsection{Microscopy}

Conventional light microscopy is not sufficient to visualize flagellar filaments because of their thinness and the swiftness. One very early approach to visualize flagella of living bacterial cells is dark field microscopy (Macnab, 1976). Since light is scattered by dirt particles reducing the contrast, it has to be considered that the medium and the specimen slides must be remarkably clean. A great advance in this field is video-enhanced differential interference-contrast microscopy (Block et al., 1991). Video microscopy combined with computer based image processing made it possible to detect very small objects like particular microtubules of $\approx 25 \mathrm{~nm}$ in diameter. Computerized image analysis offers the option to estimate values like mean cell run speed and average tumbling frequency and their variation in the presence or absence of attractants or repellents (Staropoli \& Alon, 2000). Phase-contrast video microscopy combined with the analysis of superimposed image series is a very useful tool, especially for the study of the taxis to and the motion near solid surfaces (Lauga et al., 2006). A further helpful method, although not specifically associated with flagellar motility and chemotaxis, is fluorescence microscopy, which can be used to visualize protein-protein-interactions in the chemoreceptor signaltransduction pathway and the fagellar motor, in combination with green fluorescence fusion proteins (Pierce et al., 1999; Khan et al., 2000).

\subsubsection{Chemotaxis assays}

Another easy to handle experimental set of tools is composed from different kinds of chemotaxis assays (Miller et al. 2009). One semiquantitative variant is based on changes of the opalescence of a semi-solid agar due to the concentration of bacterial cells (Hugdahl et al., 1988). In a first step, a phosphate buffered saline-agar solution is mixed with a bacterial suspension of a specifiy optical density and poured into a petri dish. After solidification, paper discs with the chemotaxins are placed onto the agar surface following incubation of three to four hours. A more opaque zone can be seen in the surrounding of chemoattractants (see Fig. 1A), whereas chemorepellents are girdled by a more transparent halo (see Fig. $1 \mathrm{~B}$ ). Other versions of the agar based chemotaxis assay deal with pure - bacteria free - agar plates. After solidification of the agar small recessions are cut into the agar and are filled with either a bacterial suspension or the test solution (Köhidai, 1995). A variation of this assay uses parallel channels (PP-technique) cut from each of both recesses connected by a third perpendicular channel between these two to facilitate diffusion of bacterial suspension and test solution (Köhidai, 1995). 

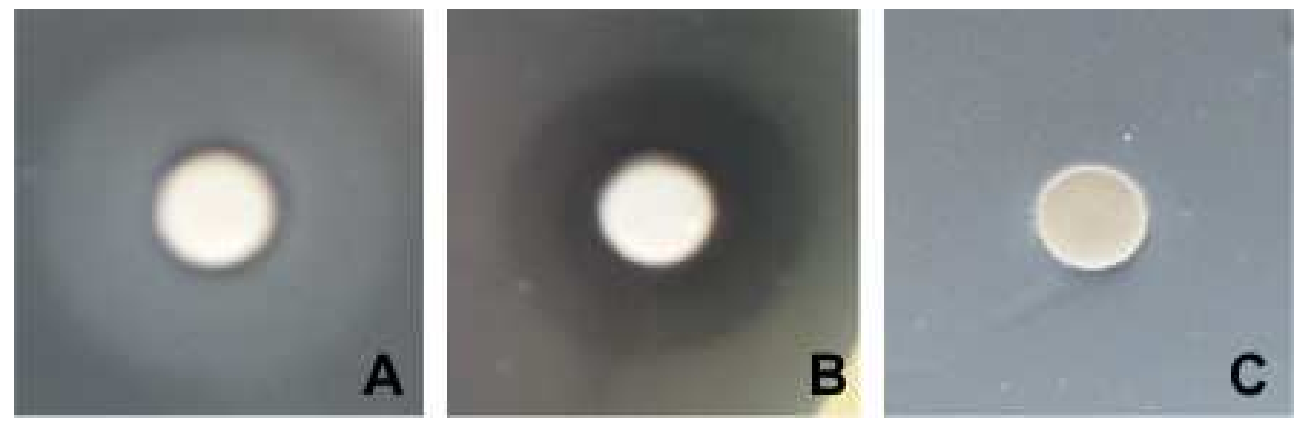

Fig. 1. Examples for chemotaxis: A: Attraction towards towards L-asparagine; B: Repulsion from deoxycholic acid; C: Control (PBS)

A second method is a capillary assay. In this assay, heparinized glass capillaries bridge between a bacterial suspension and a test solution (Koppelhus et al., 1994; Leick \& Helle, 1983). Two-phase assays in spectrophotometer plastic cuvettes are suitable to monitor the chemotaxis-mediated migration between the two fluid phases (Koppelhus et al., 1994). The T-maze assay allows the quantification of the chemoresponse of two substances in direct comparison, using a T-shaped experimental arrangement of three containers (Van Houten et al., 1982).

The use of a so-called Boyden chamber is a third variant to study chemotaxis. Chambers divided by filters are a third variant of chemotaxis assays. The suspension of motile cells is placed into the upper vessel of the so-called Boyden chamber (Boyden, 1962). The test solution with the chemoeffector is filled into the lower vessel. A filter membrane separates both parts of the Boyden chamber. The pore diameter must be chosen according to the size of the organism allowing its transmigration. To simulate in vivo conditions, the filter membranes can be optionally covered with extracellular matrix proteins like collagen, elastin or fibrin. Modifications of this technique connect the vessels either horizontally (Zigmond, 1988) or as concentric rings (Zicha et al., 1991). Multiwell chambers make the parallel testing of different substances in one occasion feasible.

\subsection{Molecular structure of the flagella motor and chemoreceptors}

\subsubsection{Molecular structure and synthesis of the flagellar apparatus}

Non-flagellar Type III secretory systems and the flagellar apparatus share a common basic architecture. Thus, it seems apparently that both go back to a common evolutionary origin (Toft \& Fares, 2008).

Basically, the flagellum is comprised of three parts: a helical filament, the hook and the basal body (see Fig. 2). The filament of bacterial flagella is built up of multiple subunits of the flagellin protein FliC (Samatey et al., 2004), which form so called protofilaments. Eleven circular arranged protofilaments stacked into a left- or right-handed helix, according to the direction of rotation (see above) comprise the filament (O'Brian \& Bennet, 1972). It has a length of about $10 \mu \mathrm{m}$ and a diameter of about $20 \mathrm{~nm}$. If a flagellum is virtually flattened, it shows a constant interspace between adjacent turns, corresponding to the wavelength of a 
"sine wave" (Madigan \& Martinko, 2006). This wavelength is specific for any bacterial species and is determined by the structure of the flagellin protein and the rotational direction of the filament (Madigan \& Martinko, 2006).

The hook tethers the filament to the basal body. Electron microscopic studies demonstrated that the hook of $S$. typhimurium has length of $55 \pm 6 \mathrm{~nm}$ (Hirano et al., 1994). The interdigitated hook-subunits make up a bended tube with a 2 to $3 \mathrm{~nm}$ wide central channel, which continues in the rod as well as in the filament (Shaik et al., 2005). The hook connects the filament to the motor portion of the flagellar apparatus. The hooks flexibility permits the transmission of torque from the motor to the helical propeller when both are not in a coaxial orientation to each other (Berg \& Anderson, 1973). A so-called gap compression/extension mechanism and mutual sliding of the hook-subunits allows continuous structural change of the hook during flagellar rotation at low energy cost (Furuta et al., 2006). The hook facilitates the synchronization of several filaments bundled together at one cell pole (Macnab, 1977; Berg \& Anderson, 1973). The two hook-associated proteins (HAP 1 and 3) form a small hook-filament junction, which acts as an adaptor for transition between the hook that is flexible in bending but rigid against twisting and the much more stiff filament (Samatey et al., 2004).

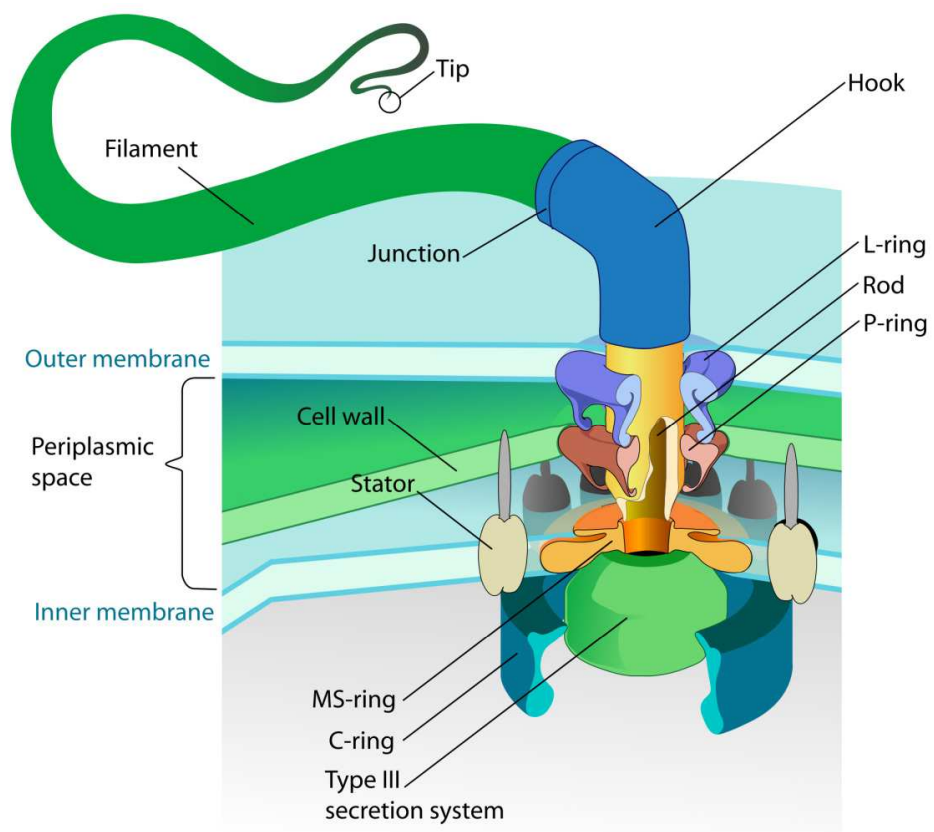

Fig. 2. The flagellum of Gram-negative bacteria, like Salmonella sp., is a complex structure consisting of the propeller like acting filament, the flexiple hook and the flagellar ATPdriven motor, which is comprised of four ring-structures and the static motor complexes. An integrated flagellar type III secretion system exports actively the proteins for flagellar assembly but also some virulence associated factors. (Copyright: Wikimedia Commons, public domain aviable from http://upload.wikimedia.org/wikipedia/commons/1/15/ Flagellum _base_diagram_en.svg) 
The third part of the flagella - the basal body is comprised of a rod sticking in four ring-like structures: the L-ring (associated with lipopolysaccharides) and the P-ring (associated with peptidoglycanes) forming an outer cylinder embedded in the plasma membrane, the MSring, building up a motor mounting plate; and the versatile C-ring (Macnab, 1999). Grampositive bacteria lacking an outer membrane lack consequentely the outer ring structures.

Overall more than 40 genes are involved in flagellar synthesis and subsequent motility in $S$. typhimurium (Shaik et al. 2005). The MS- and the C-ring, the export apparatus as well as the motor and switch are the first synthesized compounds of the flagella (Katayama et al., 1996; Macnab, 2003). The following assembly steps utilize the type III export apparatus, while the export substrates are supplied via an delivery apparatus located in a patch of membrane near the center of the MS-ring to the channel (Suzuki et al., 1998; Macnab, 2003). It follows the formation of the rod and the other two rings. The proteins of which the rod is comprised are FlgB, FlgC, FlgF and FlgG (Homma et al., 1990). The bifunctional FlgJ protein, which has a muraminidase activity to open the peptidoglycan layer for penetration of the sprouting rod, is also able to bind other rod constituents (Hirano et al., 2001), and thus may act as a rod capping protein promoting the assembly of the rod out of its four components (Nambu et al.; 1999, Macnab, 2003). The assembly of the basal body is finished by the synthesis of the periplasmic P-ring made out of FlgI (Homma et al., 1987) and the outer membrane L-ring consisting of FlgH-subunits (Jones et al., 1990). In the following step, the rod cap is dislodged, while the hook-cap, consisting of about 5 FlgD-subunits, is mounted (Macnab, 2003) and the hook is attached on the basal body. It consists, comparable to the flagellar filament, of about 120 copies of a single kind of protein, FlgE - the so-called hook protein (Samatey et al., 2004). Parallel, the L-ring is assembled (Kubori et al., 1992; Ohnishi et al., 1987). After this, two junction protein zones, made either of FlgK or FlgL, are attached, and a so-called filament-cap out of FliD-proteins is mounted on the hook (Homma et al., 1985; Ikeda et al., 1987 \& 1989). Cap proteins assist the organization of the flagellin proteins to form a new filament (Ikeda et al., 1985). Between hook and cap, a junction zone is synthesized before the protofilaments are assembled (Macnab, 2003). The flagellin molecules pass the channel inside the hook and the filament and add on successively at the lower end. The flagellar assembly starts beneath the cap and grows from its tip to its base. A mature flagellum is composed of approximately 20000 copies of flagellin protein. A broken flagella can be repaired with newly synthesized flagellin units from the cytoplasm passing through the filament channel (Homma \& Iino, 1985). The proteins, which built up the flagellum, are translocated to the distal part of the growing flagellum through the central channel by a flagellar type III homologous protein secretion system (Ibuki et al., 2011). This secretion system is comprised of two classes of proteins: soluble and membrane associated ones. The essential soluble compounds of this ATP-consuming process are the soluble FliI-ATPase, its regulator FliH and the FliJ-protein, that promotes the hexamerization of FliI-ATPases (Ibuki et al., 2011). The remaining soluble components are specific chaperones: FlgN for the hookfilament junction proteins, FliT for the filament cap protein, and FliS for flagellin (Macnab, 2003). The six membrane associated components FlhA, FlhB, FliO, FliP, FliQ, and FliR form a complex within the MS-ring (Macnab, 2003).

A rotary motor is in principle built up of two functional components: the rotor and the stator. The flagellar motor consists of the static Mot-complexes, which were affixed in the inner cytoplasmatic membrane and the rotating C-ring. The Mot-complexes are 
transmembrane structures made from two proteins MotA and MotB (Macnab, 2003). The cytoplasmic C-ring contains the motor/switch proteins - the Fli-proteins. The FliG-proteins generate the torsional moment, while working against the Mot-complexes. The switchproteins, in Salmonella sp.: FliG, FliM and FliN can reverse the flagellar rotational direction in response to intracellular signals (Francis et al., 1994; Yamaguchi et al. 1986). The FliMprotein is the final effector of a sensory transduction chain (Bren et al., 1998; Sockett et al., 1992). Thus, the stator is formed by the Mot-proteins, which mantle the C-and the MS-rings. C- and MS-rings, as well as the rod, collectively form the rotor.

Driven by a transmembrane proton gradient, the flagellar motor is able to perform the clockwise and a counterclockwise rotation of the filament, which is reversed stochastically in the absence of any stimulus. The protons are pumped from outside across the cytoplasmic membrane through the Mot-complexes. Calculations showed that about 1000 protons must be translocated to perform a single rotation of the flagellar filament. In the proposed proton pump model, the protons flowing through the stator channels exert electrostatic forces on helically arranged charge clusters on the rotor rings. Most probably, the protons bind temporary to a specific aspartate residue of MotB, causing a change of the stators conformation that drives the rotor through an elementary rotational step (Kojima \& Blair, 2001; Macnab, 2003). In the next step, the aspartate residue gets deprotonated and the stator returns to its original conformation. These resulting series of interactions between positive and negative charges generate a torsional moment as protons flow through the Mot-complexes.

\subsection{Chemoreceptor structure and signal transduction}

Presence and concentration of chemotaxins are detected by a family of chemoreceptors sharing a common two-component system architecture (Miller et al. 2009). Such twocomponent systems are generally comprised of a membrane associated histidine autokinase (CheA) and a cytoplasmic response regulator (CheY; Lux et al. 2004). Methyl-accepting chemotaxis proteins (MCPs), embedded in the cytoplasmic membrane, sense the environmental signals via their $N$-terminal periplasmic sensory domain to their $C$-terminal cytoplasmic signaling domain. The MCP-monomers have a molecular mass of about $60 \mathrm{kDa}$ and form constitutively very stable homodimers, which are arranged in groups of three (Lux et al. 2004). CheW linker proteins tether the CheA histidine kinase to the MCPs (Miller et al. 2009). This inhibits autophosphorylation of CheA, which in turn reduces the phosphorylation of CheY response regulator at a conserved histidine residue. Hypophosphorylated CheY can diffuse freely in the cytoplasm and can interact with FliM, the switch protein of the flagellar motor (Mot), which is the final effector of sensory transduction chain (Bren et al., 1998; Sockett et al., 1992). Thus, it triggers counterclockwise rotation of the flagella, which leads to bacterial "running". If a bacterium moves along a gradient of a chemoattractant, the intracellular concentration of phosphorylated CheY decreases. Consequently, the frequency of flagella switching decreases, and the number of site directed "runs" along the gradient increases. Thus, addition of an attractant triggers a counterclockwise rotation of the filament (Bren \& Eisenbach, 2000).

In the opposite case, decreasing ligand occupancy of the MCPs leads to increased autophoshorylation of CheA and in consequence to an amplified phosphorylation of CheY 
and CheB. Phosphorylated CheY binds as well to the motor switch but triggers a clockwise flagellar rotation resulting in bacterial "tumbling".

CheB is a receptor-demethylating enzyme, which is also activated by phosphorylation. The phosphatase CheZ is responsible for the dephosphorylation of phosphate-activated CheY (Bourret \& Stock, 2002).

The result of this chemosensing in three-dimensional spatial gradients of different chemoattractors and chemorepellents is a stereoscopic "zigzag" path of motion (Berg \& Brown, 1972), until the bacterium reaches a niche with an equilibrium between the varying chemoeffectors (Miller et al., 2009).

\subsection{Sensory adaptation}

Sensory adaption means reestablishment of the prestimulus state in the perpetual presence of the stimulus. Adaptation to chemotactical stimuli is mostly due to modulation of the methylation of certain sites of the MCP receptors. The central players in the process of sensory adaption are the methyltransferase CheR, the methylesterase CheB, and the cytoplasmic domains of the MCP-receptors that have adjacent to the CheA and CheW binding sites, sites for methylation and demethylation of glutamyl side chains (Macnab, 2003).

CheR catalyzes in a S-adenosylmethionine consuming reaction the methylation of the specific glutamate residues on the cytoplasmic domains of the MCPs (Bren \& Eisenbach, 2000). This reaction enhances the CheA autophosphorylation favouring clockwise flagallar rotation and is triggered by attracting stimuli (Borkovich et al., 1992; Ninfa et al., 1991). The cytoplasmatic domains of the MCPs have a specific domain, which is methylated by CheR, and a distinct CheR-binding site consisting of a pentapepetide that is only present in highabundance receptors. It was shown that CheR bound to the binding sites onto the highabundance receptors methylates the designated sites of the low-abundance receptors (Le Moual et al., 1997; Li et al., 1997).

Its antagonist is the methylesterase $\mathrm{CheB}$, which demethylates the MCPs during adaptation to repelling stimuli. Additionally $\mathrm{CheB}$ has an amidase activity catalyzing the conversion of glutamamine residues into glutamate on the MCPs (Djordjevic et al., 1998). The liberation of glutamate residues inhibits the autophosphorylation of CheA favouring a counterclockwise rotation of the flagellum. In addition CheB itself is regulated by CheA-mediated phosphorylation (Hess et al., 1988; Lupas \& Stock, 1989). Phosphorylation inhibits the methylesterase activity, while the unphosphorylated enzyme has less methylesterase activity. The binding sites on CheA for CheY and CheB are identical. Thus CheB competes with CheY (Li et al., 1995).

Furthermore a high methylation rate decreases the receptors affinity to chemoattractants (Bornhorst et al., 2000; Li et al., 2000). It was also suggested that a deferred activation of CheZ, which is responsible for an enhanced CheY dephosphorylation, is involved in the process of sensory adaptation (Blat et al., 1998).

These regulatory effects occur only after the initial chemotactic response and the steady state of all these parallel-acting adaptational processes determines the extent of reaction to a certain chemoeffector (Alon et al., 1999). 


\subsection{Specific Salmonella chemoreceptors}

Altogether, it is difficult to identify chemoreceptors specific for a certain taxin, because the different MCPs can compensate each other in many cases, Thus, knockout mutants of chemoreceptor genes show often no defects in their phenotype (Vegge et al., 2009; Tareen et al. 2010). Up to now, four chemoreceptor specificities are identified for Salmonella spp.

The Tar chemoreceptor is specific for aspartate and initiates attractant signalling (Foster et al. 1985; Milburn et al., 1991). The same receptor molecule interacts also with the periplasmic maltose-binding protein, and senses in this way chemoattraction towards maltose (Mowbray \& Koshland 1987; Gardina et al., 1992). It was also demonstrated that this receptor mediates attractant responses to phenol and repellent responses to glycerol and nickel or cobalt ions in Escherichia coli as well as thermoresponses (Lee \& Imae, 1990).

The ligand serine mediates positive taxis via the Tsr receptor, whereas Tsr sensing due to leucine and glycerol results in a repulsion of the bacteria. (Lee \& Imae, 1990; Jeffrey \& Koshland, 1993; Oosawa \& Imae, 1984; Springer et al., 1977). Tsr functions also as thermoreceptor. Temperature increase leads to smooth swimming of bacterial cells, whereas temperature decrease induces tumbling (Lee et al., 1988).

S. typhimurium demonstrates attraction towards citrate and metal-citrate complexes, but repulsion from phenol. This behavior gives the name to the third chemoreceptor in this schedule - Tcp, that stands for taxis to citrate and away from phenol (Yamamoto \& Imae, 1993).

The $\operatorname{trg}$ gene encodes a fourth chemoreceptor of the MCP family specific for ribose/galactose (Blat \& Eisenberg, 1995, Kasinkas et al. 2007).

\subsection{Virulence factors secreted via the flagellar type III secretion system}

As mentioned above, the flagellar apparatus is a homologue of a type III secretion system that is able to secrete specific peptides and proteins in an ATP dependent mechanism into the environment (Collazo \& Galán, 1996; Eichelberg et al., 1994). Among these secreted proteins are mostly structural components of the flagella, for example flagellin monomers, and the hook protein, but also several virulence factors. It functions as a molecular syringe the so-called injectisome - that is used by bacteria to inject effector proteins directly into the interior of host cells (Mota et al., 2005a+b; Arnold et al. 2009). Thus, these proteins play an important role for host cell invasion and the pathogenesis of salmonellosis. It was shown, that the $N$-terminal 30 residues of these effector proteins form a taxonomically universal, type III specific secretion signal (Arnold et al. 2009; Samurdrala et al. 2009). About 65 type III secretion system substrates are known for S. typhimurium (Samurdrala et al. 2009). Five well described proteins involved in host cell invasion, typically the M-cells of the ileal Peyers' Patches, are InvE, Sipa, Sipb, SipC, and SipD. InvE plays a pivotal role for triggering cellular mechanisms, which lead to bacterial entry. It is required for translocation of other effector proteins into the cytosol of host cells and forms complexes with SipA, SipB, and SipC. (Kubori \& Galán, 2002). Comparable to InvE the effector protein SipD, which has been shown to be important for liver and ileum colonization, is suggested to modulate the secretion of SipA, SipB, and SipC (Gong et al., 2010). Cell invasion occurs via a rufflemediated mechanism, which is initiated by the activation of specific signal transduction cascades and rearrangement of the actin cytoskeleton. The actin rearrangements are realized 
by SipA interworking with SopE, a guanine-nucleotide exchange factor for Rho GTPases, and SptP, a protein tyrosine phosphatase, (Brumell et al., 1999) as well as SipC that binds and bundles F-actin (Myeni \& Zhou, 2010).

SipB interacts after entering the cytosol of macrophages with cell signalling pathways to induce apoptosis (Hersh et al. 1999). It associates with caspase-1 and promotes the proteolytic activation of this protease.

Two further proteins entering macrophages are SrfN and PagK2, which were shown to be essential for full virulence and are suggested to interact with host cellular components (Yoon et al. 2011). These two effector proteins are translocated independently of the injectisome. Thus, the flagellar type III secretion system is the only protein export mechanism in Salmonella sp.

\subsection{Role of chemotaxis and flagellar motility for the pathoegenesis of salmonelosis}

The ability for directed movement and taxis towards and away from chemoeffectors plays a crucial role for the pathogenesis of salmonellosis. Amongst others, Salmonella bacteria are able to persist inside the inner leaf tissue of plants (Kroupitski et al., 2009; Goldberg et al., 2011). It was shown that flagellar motility and chemotaxis towards nutrients produced by photosynthetically active cells are crucial for entry into iceberg lettuce leaves via open stomata and invasion into the plant tissue (Kroupitski et al., 2009). Enteropathogens have the ability to adapt to the phyllosphere environment. They obviously interact with epiphytic bacteria (Beuchat, 2002; Brandl, 2006; Heaton \& Jones 2008) and become part of phylloplane biofilms, where they gain protection from environmental stressors (Fett, 2000). Plants that might become contaminated by the use of germ-containing water for irrigation or Salmonellacontaining liquid manure for fertilization might function as source of infection (Beuchat, \& Ryu, 1997; Brandl, 2006; Horby et al., 2003). Internal persistence after entering the plant tissue explains the failure of lavation and sanitizers to eradicate Salmonella in leafy greens.

Furthermore, flagellar movement and chemotaxis are also pivotal for the intestinal colonization of the different Salmonella hosts, especially for the competition for nutrients with other bacteria of human microbiome (Stecher et al., 2008). Even the induction of colitis depends on a functioning flagellar movement and chemotaxis (Stecher et al., 2004).

\section{Conclusion}

The flagellar apparatus is an evolutionary ancient multifunctional tool involved in motility, bacterial cell aggregation, biofilm formation, protein export, and a virulence factor injection via the injectisome. It is also the prototype of a sensing system, coupling energy taxis and motility. The research on chemotaxis and flagellar motility is almost as old as bacteriology itself, starting at the end of the 19th century. The research on Salmonella sp. plays here a special role, as most of the knowledge about thermo- and chemotaxis, MCP-receptor signal transduction, MCP-receptor sensory adaptation, structure, synthesis, and function of the flagellar apparatus as well as effector protein secretion via a flagellar type III homologue secretion system was made using Salmonella sp. and E. coli as model organism.

Thus, the flagellar apparatus regulated by energy taxis may be the most important structure for intestinal colonization and pathogenesis of salmonellosis. 


\section{Acknowledgement}

The work of the author is funded by the Forschungsförderungsprogramm of the Universitätsmedizin Göttingen, Germany and by the Deutsche Forschungsgemeinschaft (PAK 400).

\section{References}

Adler, J. (1975) Chemotaxis in Bacteria. Annual Review of Biochemistry, Vol. 44, (1975), pp. 341-356, ISSN 0066-4154

Alon, U., Surette, M.G., Barkai, N. \& Leibler, S. (1999). Robustness in bacterial chemotaxis. Nature, Vol. 397, No. 6715, (January 1999), pp. 168-171, ISSN 0369-3392

Arnold, R., Brandmaier, S., Kleine, F., Tischler, P., Heinz, E., Behrens, S, Niinikoski, A., Mewes, H.W., Horn, M. \& Rattei, T. (2009) Sequence-based prediction of type III secreted proteins. PLoS Pathogens. Vol. 5, No. 4, (April 2009), pp. e1000376, ISSN 1553-7366

Barnakov, A.N., Barnakova, L.A. \& Hazelbauer, G.L. (1999). Efficient adaptational demethylation of chemoreceptors requires the same enzyme-docking site as efficient methylation. Proceedings of the National Academy of Sciences of the United States of America. No. 96, Vol. 19, (September 1999), pp. 10667-10672, ISSN 0027-8424

Berg, H.C. \& Anderson, R.A. (1973). Bacteria swim by rotating their flagellar filaments. Nature. Vol. 245, No. 5425, (October 1973), pp. 380-282, ISSN 0028-0836

Berg, H.C. \& Brown D.A. (1972). Chemotaxis in Escherichia coli analysed by three-dimensional tracking. Nature. Vol. 239, No. 5374, (October 1972), pp 500-504, ISSN 0028-0836

Beuchat L.R. (2002). Ecological factors influencing survival and growth of human pathogens on raw fruits and vegetables. Microbes and infection / Institut Pasteur. Vol. 4, No. 4), (April 2002), pp. 413-423, ISSN 1286-4579

Beuchat, L.R. \& Ryu, J.H. (1997). Produce handling and processing practices. Emerging infectious diseases. Vol. 3, No. 4, (October-December 1997), pp. 459-465., ISSN 10806040

Blat, Y. \& Eisenbach, M. (1995). Tar-dependent and -independent pattern formation by Salmonella typhimurium. Journal of bacteriology. Vol. 177, No. 7, (April 1995), pp. 16831691, ISSN 0021-9193

Blat, Y., Gillespie, B., Bren, A., Dahlquist, F.W. \& Eisenbach, M. (1998). Regulation of phosphatase activity in bacterial chemotaxis. Journal of molecular biology. Vol. 284, No, 4, (December 1998), pp. 1191-1199, ISSN 0022-2836

Block, S.M., Fahrner, K.A. \& Berg, H.C. (1991). Visualization of bacterial flagella by videoenhanced light microscopy. Journal of Bacteriology, Vol. 173, No. 2, (January 1991), pp. 933-936, ISSN 0021-9193

Borkovich, K.A., Alex, L.A. \& Simon, M.I. (1992). Attenuation of sensory receptor signaling by covalent modification. Proceedings of the National Academy of Sciences of the United States of America. Vol. 89, No. 15, (August 1992), pp. 6756-6760, ISSN 0027-8424

Bornhorst, J.A. \& Falke, J.J. (2000). Attractant regulation of the aspartate receptor-kinase complex: limited cooperative interactions between receptors and effects of the receptor modification state. Biochemistry. Vol. 39, No. 31, (August 2000), pp. 94869493, ISSN 0006-2960 
Bourret, R.B. \& Stock, A.M. (2002). Molecular information processing: lessons from bacterial chemotaxis. The Journal of biological chemistry. Vol. 277, No. 12, (March 2002), pp. 9625-9628, ISSN 0021-9258

Boyden, S.V. (1962). The chemotactic effect of mixtures of antibody and antigen on polymorphonuclear leucocytes. The Journal of Experimental Medicine, (February 1962), Vol. 115, No. 3, pp. 453-466, ISSN 0022-1007

Brandl, M.T. (2006). Fitness of human enteric pathogens on plants and implications for food safety. Annual review of phytopathology. Vol. 44, (2006), pp. 367-392, ISSN 0066-4286

Bren, A. \& Eisenbach, M. (1998). The $N$ terminus of the flagellar switch protein, FliM, is the binding domain for the chemotactic response regulator, CheY. Journal of molecular biology. Vol. 278, No. 3, (May 1998), pp. 507-514. ISSN 0022-2836

Bren, A. \& Eisenbach, M. (2000). How signals are heard during bacterial chemotaxis: protein-protein interactions in sensory signal propagation. Journal of bacteriology. Vol. 182, No. 24, (December 2000), pp. 6865-6873, ISSN 0021-9193

Brumell, J.H., Steele-Mortimer, O. \& Finlay, B.B. (1999). Bacterial invasion: Force feeding by Salmonella. Current biology. Vol. 9, No. 8, (April 1999), pp. R277-80, ISSN 0960-9822

Collazo, C.M. \& Galán, J.E. (1996). Requirement for exported proteins in secretion through the invasion-associated type III system of Salmonella typhimurium. Infection and immunity. Vol. 64, No. 9. (September 1996) pp. 3524-3531, ISSN 0019-9567

Djordjevic, S. \& Stock, A.M. (1998). Structural analysis of bacterial chemotaxis proteins: components of a dynamic signaling system. Journal of structural biology. Vol. 124, No. 2-3, (December 1998), pp. 189-200, ISSN 1047-8477

Eichelberg, K., Ginocchio, C.C. \& Galán, J.E. (1994). Molecular and functional characterization of the Salmonella typhimurium invasion genes invB and invC: homology of InvC to the F0F1 ATPase family of proteins. Journal of bacteriology. Vol. 176, No. 15, (August 1994), pp. 4501-4510, ISSN 0021-9193

Engelmann, T.W. (1881). Neue Methode zur Untersuchung der Sauerstoffausscheidung pflanzlicher und thierischer Organismen. Pflügers Archiv für die Gesamte Physiolgie der Menschen und Tiere, Vol. 25, (1881) pp. 285-292, ISSN 0365-267X

Erdem, A.L., Avelino, F., Xicohtencatl-Cortes. J. \& Girón J.A. (2007). Host protein binding and adhesive properties of $\mathrm{H} 6$ and $\mathrm{H} 7$ flagella of attaching and effacing Escherichia coli. Journal of Bacteriology. Vol. 189, No. 20, (October 2007), pp. 7426-7435, ISSN 0021-9193

Fett W.F. (2000). Naturally occurring biofilms on alfalfa and other types of sprouts. Journal of food protection. Vol. 63, No. 5, (May 2000), pp. 625-632, ISSN 0362-028X

Foster, D.L., Mowbray, S.L., Jap, B.K. \& Koshland D.E. Jr. (1985). Purification and characterization of the aspartate chemoreceptor. The Journal of biological chemistry. Vol. 260, No. 21, (September 1985), pp. 11706-11710, ISSN 0021-9258

Francis, N.R., Sosinsky, G.E., Thomas, D. \& DeRosier, D.J. (1994). Isolation, characterization and structure of bacterial flagellar motors containing the switch complex. Journal of molecular biology. Vol. 235, No. 4, (January 1994), pp. 1261-1270; ISSN 0022-2836

Frye, J., Karlinsey, J.E., Felise, H.R., Marzolf, B., Dowidar, N., McClelland, M. \& Hughes, K.T. (2006). Identification of new flagellar genes of Salmonella enterica serovar Typhimurium. Journal of Bacteriology, Vol. 188, No. 6, (March 2006), pp. 2233-2243, ISSN 0021-9193

Furuta, T., Samatey, F.A., Matsunami, H., Imada, K., Namba, K. \& Kitao, A. (2007). Gap compression/extension mechanism of bacterial flagellar hook as the molecular 
universal joint. Journal of Structural Biology, Vol. 157, No. 3, (March 2007), pp. 481490, ISSN 1047-8477

Gardina, P., Conway, C., Kossman, M. \& Manson, M. (1992). Aspartate and maltose-binding protein interact with adjacent sites in the Tar chemotactic signal transducer of Escherichia coli. Journal of bacteriology. Vol. 174, No. 5, (March 1992), pp.1528-1536, ISSN 0021-9193

Gebremichael Y, Ayton GS, Voth GA. (2006). Mesoscopic modeling of bacterial flagellar microhydrodynamics. Biophysical Journal. Vol. 91, No. 10, (November 2006), pp. 3640-3652, ISSN 0006-3495

Golberg, D., Kroupitski, Y., Belausov, E., Pinto, R. \& Sela, S. (2011). Salmonella Typhimurium internalization is variable in leafy vegetables and fresh herbs. International journal of food microbiology. Vol. 145, No. 1, (January 2011), pp. 250-257, ISSN 0168-1605

Gong, H., Vu, G.P., Bai, Y., Yang, E., Liu, F. \& Lu, S. (2010). Differential expression of Salmonella type III secretion system factors InvJ, PrgJ, SipC, SipD, SopA and SopB in cultures and in mice. Microbiology. Vol. 156, No. Pt 1, (January 2010), pp. 116-127, ISSN 1350-0872

Hahn, H., Klein, P., Giesbrecht, R.E. \& Streeck, R.E. (2004). Bakterien: Definition und Aufbau, In: Medizinische Mikrobiologie und Infektologie, Hahn, H., Falke, D., Kaufmann, S.H.E. \& Ullmann, U., pp. 169-179, Springer Medizin Verlag Heidelberg, ISBN 3-540-21971-4, Berlin, Germany

Heaton, J.C. \& Jones, K. (2008). Microbial contamination of fruit and vegetables and the behaviour of enteropathogens in the phyllosphere: a review. Journal of applied microbiology. Vol. 104, No. 3, (March 2008), pp. 613-626, ISSN $1364-5072$

Hersh, D., Monack, D.M., Smith, M.R., Ghori, N., Falkow, S. \& Zychlinsky, A. (1999). The Salmonella invasin SipB induces macrophage apoptosis by binding to caspase-1. Proceedings of the National Academy of Sciences of the United States of America. Vol. 96, No. 5, (March 1999), pp. 2396-2401, ISSN 0027-8424

Hess, J.F., Oosawa, K., Kaplan, N. \& Simon, M.I. (1988). Phosphorylation of three proteins in the signaling pathway of bacterial chemotaxis. Cell. Vol. 53, No. 1, (April 1988), pp. 79-87, ISSN 0092-8674

Hirano, T., Minamino, T. \& Macnab, R.M. (2001). The role in flagellar rod assembly of the Nterminal domain of Salmonella FlgJ, a flagellum-specific muramidase. Journal of molecular biology. Vol. 312, No. 2, (September 2001), pp. 359-369, ISSN 0022-2836

Hirano, T., Yamaguchi, S., Oosawa, K. \& Aizawa, S. (1994). Roles of FliK and FlhB in determination of flagellar hook length in Salmonella typhimurium. Journal of bacteriology. Vol. 176, No. 17, (September 1994) pp. 5439-5449, ISSN 0021-9193

Homma, M. \& Iino. T. Excretion of unassembled hook-associated proteins by Salmonella typhimurium. (1985). Journal of bacteriology. Vol. 164, No. 3, (December 1985), pp. 1370-1372, ISSN 0021-9193

Homma, M., Komeda, Y., Iino, T. \& Macnab, R.M. (1987). The flaFIX gene product of Salmonella typhimurium is a flagellar basal body component with a signal peptide for export. Journal of bacteriology. Vol. 169, No. 4, (April 1987), pp. 1493-1498, ISSN 0021-9193

Homma, M., Kutsukake, K. \& Iino, T. (1985). Structural genes for flagellar hook-associated proteins in Salmonella typhimurium. Journal of bacteriology. Vol. 163, No. 2, (August 1985), pp. 464-471, ISSN 0021-9193 
Homma, M., Kutsukake, K., Hasebe, M., Iino, T, \& Macnab R.M. (1990). FlgB, FlgC, FlgF and FlgG. A family of structurally related proteins in the flagellar basal body of Salmonella typhimurium. Journal of molecular biology. Vol. 211, No. 2, (January 1990), pp. 465-477, ISSN 0022-2836

Horby, P.W., O'Brien, S.J., Adak, G.K., Graham, C., Hawker, J.I., Hunter, P., Lane, C., Lawson, A.J., Mitchell, R.T., Reacher, M.H., Threlfall, E.J., Ward, L.R. \& PHLS Outbreak Investigation Team (2003). A national outbreak of multi-resistant Salmonella enterica serovar Typhimurium definitive phage type (DT) 104 associated with consumption of lettuce. Epidemiology and infection. Vol. 130, No. 2, (April 2003), pp. 169-178, ISSN 0950-2688

Hugdahl, M.B., Beery, J.T. \& Doyle MP. (1988). Chemotactic behavior of Campylobacter jejuni, Infection and Immunity, Vol. 56, No. 6, (June 1988), pp.1560-1566, ISSN 0019-9567

Ibuki, T., Imada, K., Minamino, T., Kato, T., Miyata, T. \& Namba, K. (2011) Common architecture of the flagellar type III protein export apparatus and F- and V-type ATPases. Nature structural \& molecular biology. Vol. 18, No. 3, (March 2011), pp. 277282 , ISSN 1545-9993

Ikeda, T., Asakura, S. \& Kamiya, R. (1985). "Cap" on the tip of Salmonella flagella. Journal of molecular biology. Vol. 184, No. 4, (August 1985), pp. 735-737, ISSN 0022-2836

Ikeda, T., Asakura, S. \& Kamiya, R. (1989). Total reconstitution of Salmonella flagellar filaments from hook and purified flagellin and hook-associated proteins in vitro. Journal of molecular biology. Vol. 209, No. 1, (Sep 1989), pp. 109-114, ISSN 0022-2836

Ikeda, T., Homma, M., Iino, T., Asakura, S. \& Kamiya, R. (1987). Localization and stoichiometry of hook-associated proteins within Salmonella typhimurium flagella. Journal of bacteriology. Vol. 169, No. 3, (March 1987), pp.1168-1173, ISSN 0021-9193

Iwama, T., Ito, Y., Aoki, H., Sakamoto, H., Yamagata, S., Kawai, K. \& Kawagishi I. (2006). Differential recognition of citrate and a metal-citrate complex by the bacterial chemoreceptor Tcp. The Journal of Biological Chemistry, Vol. 281, No. 26, (June 2006), pp. 17727-17735, ISSN 0021-9258

Jeffery, C.J. \& Koshland, D.E. Jr. Three-dimensional structural model of the serine receptor ligand-binding domain. Protein science: a publication of the Protein Society. Vol. 2, No. 4, (April 1993), pp. 559-566, ISSN 0961-8368

Jones, C.J. \& Aizawa S. (1991). Genetic control of the bacterial flagellar regulon. Current opinion in genetics $\mathcal{E}$ development, Vol. 1, No. 3, (October 1991), 319-923, ISSN 0959-437X

Jones, C.J., Macnab, R.M., Okino, H. \& Aizawa, S. (1990). Stoichiometric analysis of the flagellar hook-(basal-body) complex of Salmonella typhimurium. Journal of molecular biology. Vol. 212, No. 2, (March 1990), pp. 377-387, ISSN 0022-2836

Kasinskas, R.W. \& Forbes, N.S. (2007). Salmonella typhimurium lacking ribose chemoreceptors localize in tumor quiescence and induce apoptosis. Cancer Research, Vol. 67, No. 7, (April 2007), pp. 3201-3209, ISSN 0008-5472

Katayama, E., Shiraishi, T., Oosawa, K., Baba, N. \& Aizawa, S. (1996). Geometry of the flagellar motor in the cytoplasmic membrane of Salmonella typhimurium as determined by stereo-photogrammetry of quick-freeze deep-etch replica images. Journal of molecular biology. Vol. 255, No. 3, (January 1996), pp. 458-475, ISSN 0022-2836

Khan, S., Pierce, D. \& Vale, R.D. (2000). Interactions of the chemotaxis signal protein CheY with bacterial flagellar motors visualized by evanescent wave microscopy. Current Biology, Vol. 10, No. 15, (July - August 2000), pp. 927-930, ISSN 0960-9822 
Kitao, A., Yonekura, K., Maki-Yonekura, S., Samatey, F.A., Imada, K., Namba, K. \& Go, N. (2006). Switch interactions control energy frustration and multiple flagellar filament structures. Proceedings of the National Academy of Sciences of the United States of America. Vol. 103, No. 13 (March 2006), pp. 4894-4899, ISSN 0027-8424

Köhidai L. (1995). Method for determination of chemoattraction in Tetrahymena pyriformis. Current Microbiology. Vol. 30, No. 4 (April 1995), pp. 251-253, ISSN 0343-8651

Kojima, S. \& Blair, D.F. (2001). Conformational change in the stator of the bacterial flagellar motor. Biochemistry. Vol. 40, No. 43, (October 2001), pp. 13041-13050, ISSN 0006-2960

Koppelhus, U., Hellung-Larsen, P. \& Leick V. (1994). An improved quantitative assay for chemokinesis in Tetrahymena. The Biological Bulletin (Marine Biological Laboratory). Vol. 187, No. 1, (August 1994), pp. 8-15, ISSN 0006-3185

Kroupitski, Y., Golberg, D., Belausov, E., Pinto, R., Swartzberg, D., Granot, D. \& Sela, S. (2009). Internalization of Salmonella enterica in leaves is induced by light and involves chemotaxis and penetration through open stomata. Applied and environmental microbiology. Vol. 75, No. 19, (October 2009), pp. 6076-6086, ISSN 0099-2240

Kubori, T. \& Galán, J.E (2002). Salmonella type III secretion-associated protein InvE controls translocation of effector proteins into host cells. Journal of bacteriology. Vol. 184, No. 17, (September 2002), pp. 4699-4708, ISSN 0021-9193

Kubori, T., Matsushima, Y., Nakamura, D., Uralil, J., Lara-Tejero, M., Sukhan, A., Galán, J.E. \& Aizawa, S.I. (1998). Supramolecular structure of the Salmonella typhimurium type III protein secretion system. Science. Vol. 280, No. 5363, (April 1998), pp. 602605, ISSN 0036-8075

Larsen, S.H., Reader, R.W., Kort, E.N., Tso, W.W. \& Adler J. (1974). Change in direction of flagellar rotation is the basis of the chemotactic response in Escherichia coli. Nature. Vol. 249, No. 452, (May 1974), pp. 74-77, ISSN 0028-0836

Lauga, E., DiLuzio, W.R., Whitesides, G.M. \& Stone, H.A. (2006). Swimming in circles: motion of bacteria near solid boundaries. Biophysical Journal, Vol. 90, No. 2, (January 2006), pp. 400-412, ISSN 0006-3495

Le Moual, H., Quang, T. \& Koshland, D.E. Jr. (1997). Methylation of the Escherichia coli chemotaxis receptors: intra- and interdimer mechanisms. Biochemistry. Vol. 36, No. 43, (October 1997), pp. 13441-13448, ISSN 0006-2960

Lee, L. \& Imae, Y. (1990). Role of threonine residue 154 in ligand recognition of the tar chemoreceptor in Escherichia coli. Journal of bacteriology. Vol. 172, No. 1, (January 1990), pp. 377-382, ISSN 0021-9193

Lee, L., Mizuno, T. \& Imae, Y. (1988). Thermosensing properties of Escherichia coli tsr mutants defective in serine chemoreception. Journal of bacteriology. Vol. 170, No. 10, (October 1988), pp. 4769-4774, ISSN 0021-9193

Leick, V. \& Helle, J. (1983). A quantitative assay for ciliate chemotaxis. Analytical Biochemistry, Vol. 135, No. 2, (December 1983), pp. 466-469, ISSN: 0003-2697

Li, G. \& Weis, R.M. (2000). Covalent modification regulates ligand binding to receptor complexes in the chemosensory system of Escherichia coli. (2000) Cell. Vol. 100, No. 3, (February 2000), pp. 357-365, ISSN 0092-8674

Li, J., Li, G. \& Weis, R.M. (1997). The serine chemoreceptor from Escherichia coli is methylated through an inter-dimer process. Biochemistry. Vol. 36, No. 39, (September 1997), pp. 11851-11857, ISSN 0006-2960 
Li, J., Swanson, R.V., Simon, M.I. \& Weis, R.M. (1995). The response regulators CheB and CheY exhibit competitive binding to the kinase CheA. Biochemistry. Vol. 34, No. 45, (November 1995), pp. 14626-14636, ISSN 0006-2960

Lupas, A. \& Stock, J. (1989). Phosphorylation of an $\mathrm{N}$-terminal regulatory domain activates the CheB methylesterase in bacterial chemotaxis. The Journal of biological chemistry. Vol. 264, No. 29, (October 1989), pp. 17337-17342, ISSN 0021-9258

Lux, R. \& Shi, W. (2004). Chemotaxis-guided movements in bacteria. Critical Reviews in Oral Biology E Medicine, Vol. 15, No. 4, (July 2004), pp. 207-220, ISSN 1045-4411

Macnab, R.M. (1977). Bacterial flagella rotating in bundles: a study in helical geometry. Proceedings of the National Academy of Sciences of the United States of America. Vol. 74, No. 1, (January 1977) pp. 221-225, ISSN 0027-8424

Macnab, R.M. (1999). The bacterial flagellum: reversible rotary propellor and type III export apparatus. Journal of Bacteriology, Vol. 181, No. 23, (December 1999), pp.7149-7153, ISSN 0021-9193

Macnab, R.M. (2003). How bacteria assemble flagella. Annual review of microbiology. Vol. 57, (May 2003), pp. 77-100, ISSN 0066-4227

Macnab, R.M. (2004). Type III flagellar protein export and flagellar assembly. Biochimica et biophysica acta. Vol. 1694, No. 1-3, (November 2004), pp. 207-217, ISSN 0006-3002

Macnab, R.M. Examination of bacterial flagellation by dark-field microscopy. (1976). Journal of Clinical Microbiology. Vol. 4, No. 3, (September 1976), pp. 2582-65, ISSN 0095-1137

Madigan, M.T. \& Martinko, J. M. (2006). Mirobial locomation, In: Brock's Biology of Microorganisms 11th Edition, pp. 91-100, ISBN 0-13-196893-9, Upper Saddle River, New Jersey, USA

Mariconda, S., Wang. Q. \& Harshey, R.M. (2006). A mechanical role for the chemotaxis system in swarming motility. Molecular Microbiology, Vol. 60, No. 6, (June 2006), pp. 1590-1602, ISSN 0950-382X

Milburn, M.V., Privé, G.G., Milligan, D.L., Scott, W.G., Yeh, J., Jancarik, J., Koshland, D.E. Jr. \& Kim, S.H. Three-dimensional structures of the ligand-binding domain of the bacterial aspartate receptor with and without a ligand. Science. Vol. 254, No. 5036, (November 1991), pp. 1342-1347, ISSN 0036-8075

Miller, L.D., Russell, M.H. \& Alexandre, G. (2009). Diversity in bacterial chemotactic responses and niche adaptation. Advances in Applied Microbiology, Vol. 66, (2009), pp. 53-57, ISSN 0065-2164

Mota LJ, Journet L, Sorg I, Agrain C, Cornelis GR. (2005a). Bacterial injectisomes: needle length does matter. Science. Vol. 307, No. 5713, (February 2005), pp. 1278, ISSN 0036-8075

Mota, L.J., Sorg, I. \& Cornelis, G.R. (2005b). Type III secretion: the bacteria-eukaryotic cell express. FEMS Microbiol Letters. Vol. 252, No. 1, (November 2005), pp. 1-10, ISSN 0378-1097

Mowbray, S.L. \& Koshland, D.E. Jr. (1987). Additive and independent responses in a single receptor: aspartate and maltose stimuli on the tar protein. Cell. Vol. 50, No. 2, (July 1987), pp. 171-180, ISSN 0092-8674

Myeni, S.K. \& Zhou D. (2010). The C terminus of SipC binds and bundles F-actin to promote Salmonella invasion. The Journal of biological chemistry. Vol. 285, No. 18, (April 2010), pp. 13357-13363, ISSN 0021-9258

Nambu, T., Minamino, T., Macnab, R.M. \& Kutsukake, K. (1999). Peptidoglycanhydrolyzing activity of the FlgJ protein, essential for flagellar rod formation in 
Salmonella typhimurium. Journal of bacteriology. Vol. 181, No. 5, (March 1999), pp. 1555-1561, ISSN 0021-9193

Ninfa, E.G., Stock, A., Mowbray, S. \& Stock, J. (1991). Reconstitution of the bacterial chemotaxis signal transduction system from purified components. The Journal of biological chemistry. Vol. 266, No. 15, (May 1991), pp. 9764-9770, ISSN 0021-9258

O'Brien E.J. \& Bennett, P.M. (1972). Structure of straight flagella from a mutant Salmonella. Journal of molecular biology. Vol. 70, No. 1, (September 1972), pp. 133-152, ISSN 00222836

Ohnishi, K., Homma, M., Kutsukake, K. \& Iino, T. (1987). Formation of flagella lacking outer rings by flaM, flaU, and flaY mutants of Escherichia coli. Journal of bacteriology. Vol. 169, No. 4, (April 1987), pp.1485-1488, ISSN 0021-9193

Oosawa, K. \& Imae, Y. Demethylation of methyl-accepting chemotaxis proteins in Escherichia coli induced by the repellents glycerol and ethylene glycol. Journal of bacteriology. Vol. 157, No. 2, (February 1984), pp. 576-581, ISSN 0021-9193

O'Toole, G.A. \& Kolter, R. (1998). Flagellar and twitching motility are necessary for Pseudomonas aeruginosa biofilm development. Molecular Microbiology, Vol. 30, No. 2, (October 1998), pp. 295-304, ISSN 0950-382X

Pfeffer, W. (1884). Locomotorische Richtungsbewegungen durch chemische Reize. Untersuchungen aus dem Botanischen Institut zu Tübingen, Vol. 1, No. III, (1884), pp. 363-482, Aviable from http://www.archive.org/stream/untersuchungena01pfefgoog\#page/n4/mode/2up

Pfeffer, W. (1888). Über chemotaktische Bewegungen Von Bakterien, Flagellaten und Volvocineen. Untersuchungen aus dem Botanischen Institut zu Tübingen Vol. 2, No. III, (1888), pp. 582-661, Aviable from

http://www.archive.org/stream/untersuchungena00pfefgoog\#page/n3/mode/2up

Pierce, D.W. \& Vale, R.D. (1999). Single-molecule fluorescence detection of green fluorescence protein and application to single-protein dynamics. Methods in Cell Biology. Vol. 58, (1999), pp. 49-73, ISSN 0091-679X

Samatey, F.A., Matsunami, H., Imada K, Nagashima, S., Shaikh, T.R., Thomas, D.R., Chen, J.Z., Derosier, D.J., Kitao, A. \& Namba, K. (2004). Structure of the bacterial flagellar hook and implication for the molecular universal joint mechanism. Nature. Vol. 431, No. 7012, (October 2004), pp. 1062-1068, ISSN 0028-0836

Samudrala, R., Heffron, F. \& McDermott, J.E. (2009). Accurate prediction of secreted substrates and identification of a conserved putative secretion signal for type III secretion systems. PLoS Pathogens. Vol. 5, No. 4, (April 2009), pp. e1000375, ISSN 1553-7366

Shaikh, T.R., Thomas, D.R., Chen, J.Z., Samatey, F.A., Matsunami, H., Imada, K., Namba, K. \& Derosier, D.J. (2005). A partial atomic structure for the flagellar hook of Salmonella typhimurium. Proceedings of the National Academy of Sciences of the United States of America. Vol. 102, No. 4 (January 2005), pp. 1023-1028, , ISSN 0027-8424

Sockett, H., Yamaguchi, S., Kihara, M., Irikura, V.M. \& Macnab, R.M. (1992). Molecular analysis of the flagellar switch protein FliM of Salmonella typhimurium. Journal of bacteriology. Vol. 174, No. 3, (February 1992) pp. 793-806, ISSN 0021-9193

Springer, M.S., Goy, M.F. \& Adler, J. Sensory transduction in Escherichia coli: two complementary pathways of information processing that involve methylated proteins. Proceedings of the National Academy of Sciences of the United States of America. Vol. 74, No. 8, (August 1977), pp. 3312-3316, ISSN 0027-8424 
Staropoli, J.F. \& Alon, U. (2000). Computerized analysis of chemotaxis at different stages of bacterial growth. Biophysical Journal, Vol. 78, No. 1, (January 2000), pp. 513-519, ISSN 0006-3495

Stecher, B., Barthel, M., Schlumberger, M.C., Haberli, L., Rabsch, W., Kremer, M. \& Hardt, W.D. (2008). Motility allows S. Typhimurium to benefit from the mucosal defence. Cellular microbiology. Vol. 10, No. 5, (May 2008), pp. 1166-1180, ISSN 1462-5814

Stecher, B., Hapfelmeier, S., Müller, C., Kremer, M., Stallmach, T. \& Hardt W.D. (2004). Flagella and chemotaxis are required for efficient induction of Salmonella enterica serovar Typhimurium colitis in streptomycin-pretreated mice. Infection and Immunity, Vol. 72, No. 7, (July 2004), pp. 4138-4150, ISSN 0019-9567

Suzuki, H., Yonekura, K., Murata, K., Hirai, T., Oosawa, K. \& Namba, K. (1998). A structural feature in the central channel of the bacterial flagellar FliF ring complex is implicated in type III protein export. Journal of structural biology. Vol. 124, No. 2-3, (December 1998), pp. 104-114, ISSN 1047-8477

Tareen, A.M., Dasti, J.I., Zautner, A.E., Groß, U. \& Lugert R. Campylobacter jejuni proteins Cj0952c and Cj0951c affect chemotactic behaviour towards formic acid and are important for invasion of host cells. Microbiology. Vol. 156, No. Pt 10, (October 2010), pp. 3123-3135, ISSN 1350-0872

Toft, C. \& Fares, M.A. (2008). The evolution of the flagellar assembly pathway in endosymbiotic bacterial genomes. Molecular biology and evolution. Vol. 25, No. 9, (September 2008), pp. 2069-2076, ISSN 0737-4038

Ulett, G.C., Webb, R.I. \& Schembri, M.A. (2006). Antigen-43-mediated autoaggregation impairs motility in Escherichia coli. Microbiology. Vol. 152, No. PT 7, (July 2006), pp. 2101-2110, ISSN 1350-0872

Van Houten, J., Martel, E. \& Kasch T. (1982). Kinetic analysis of chemokinesis of Paramecium. The Journal of Protozoology, Vol. 29, No. 2, (May 1982), pp. 226-230, ISSN 0022-3921

Vegge, C.S., Brøndsted, L., Li, Y.P., Bang, D.D. \& Ingmer, H. (2009). Energy taxis drives Campylobacter jejuni toward the most favorable conditions for growth. Applied and environmental microbiology. Vol. 75, No. 16, (August 2009), pp. 5308-5314, ISSN 00992240

Yamaguchi, S., Fujita, H., Ishihara, A., Aizawa, S. \& Macnab, R.M. (1986). Subdivision of flagellar genes of Salmonella typhimurium into regions responsible for assembly, rotation, and switching. Journal of bacteriology, Vol. 166, No. 1, (April 1986), pp. 187193, ISSN 0021-9193

Yamamoto, K. \& Imae, Y. (1993). Cloning and characterization of the Salmonella typhimurium-specific chemoreceptor Tcp for taxis to citrate and from phenol. Proceedings of the National Academy of Sciences of the United States of America. Vol. 90, No. 1, (January 1993), pp. 217-221, ISSN 0027-8424

Yoon, H., Ansong, C., McDermott, J.E., Gritsenko, M., Smith, R.D., Heffron, F. \& Adkins J.N. (2011). Systems analysis of multiple regulator perturbations allows discovery of virulence factors in Salmonella. BMC systems biology. Vol. 5, No. 1, (June 2011) pp. 100, ISSN 1752-0509

Zicha, D., Dunn, G.A. \& Brown A.F. (1991). A new direct-viewing chemotaxis chamber. Journal of Cell Science, (August 1991), Vol. 99, No. 4, pp. 769-775, ISSN: 0021-9533

Zigmond, S.H. (1988). Orientation chamber in chemotaxis. Methods in Enzymology, Vol 162, (November 2003), pp. 65-72, ISSN 0076-6879 


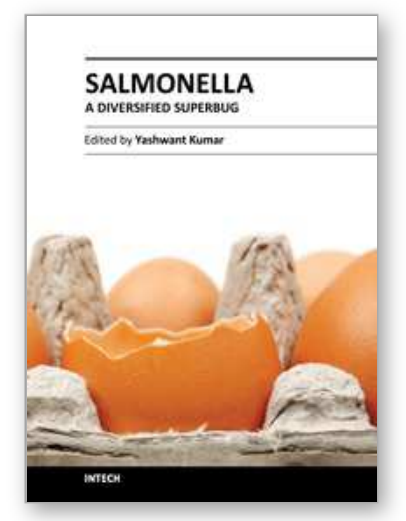

\author{
Salmonella - A Diversified Superbug \\ Edited by Mr. Yashwant Kumar
}

ISBN 978-953-307-781-9

Hard cover, 576 pages

Publisher InTech

Published online 20, January, 2012

Published in print edition January, 2012

Salmonella is an extremely diversified genus, infecting a range of hosts, and comprised of two species: enterica and bongori. This group is made up of 2579 serovars, making it versatile and fascinating for researchers drawing their attention towards different properties of this microorganism. Salmonella related diseases are a major problem in developed and developing countries resulting in economic losses, as well as problems of zoonoses and food borne illness. Moreover, the emergence of an ever increasing problem of antimicrobial resistance in salmonella makes it prudent to unveil different mechanisms involved. This book is the outcome of a collaboration between various researchers from all over the world. The recent advancements in the field of salmonella research are compiled and presented.

\title{
How to reference
}

In order to correctly reference this scholarly work, feel free to copy and paste the following:

Andreas E. Zautner (2012). Motility and Energy Taxis of Salmonella spp., Salmonella - A Diversified Superbug, Mr. Yashwant Kumar (Ed.), ISBN: 978-953-307-781-9, InTech, Available from:

http://www.intechopen.com/books/salmonella-a-diversified-superbug/motility-and-energy-taxis-of-salmonellaspp-

\section{INTECH}

open science | open minds

\section{InTech Europe}

University Campus STeP Ri

Slavka Krautzeka 83/A

51000 Rijeka, Croatia

Phone: +385 (51) 770447

Fax: +385 (51) 686166

www.intechopen.com

\section{InTech China}

Unit 405, Office Block, Hotel Equatorial Shanghai

No.65, Yan An Road (West), Shanghai, 200040, China

中国上海市延安西路65号上海国际贵都大饭店办公楼 405 单元

Phone: +86-21-62489820

Fax: +86-21-62489821 
(C) 2012 The Author(s). Licensee IntechOpen. This is an open access article distributed under the terms of the Creative Commons Attribution 3.0 License, which permits unrestricted use, distribution, and reproduction in any medium, provided the original work is properly cited. 